\title{
Nutrient requirement, canopy development and fruit yield of high density guava (Psidium guajava L.) production in subtropics of Northern Karnataka
}

\section{Mushtaq*}

Department of Horticulture, College of Agriculture, Raichur, University of Agricultural Sciences, Raichur- 584104 (Karnataka)

\section{A. R. Kurubar}

Department of Horticulture, College of Agriculture, Raichur, University of Agricultural Sciences, Raichur- 584104 (Karnataka)

\section{R. Umesh}

Department of Agronomy, University of Agricultural Sciences, Raichur- 584104 (Karnataka) Shekharagouda Patil

Department of Horticulture, College of Agriculture, Raichur, University of Agricultural Sciences, Raichur- 584104 (Karnataka)

\section{Ashok Hugar}

Department of Horticulture, College of Agriculture, Raichur, University of Agricultural Sciences, Raichur- 584104 (Karnataka)

*Corresponding author. E-mail: mrumeshagri@gmail.com

\begin{abstract}
Nutrient requirement for guava under high density planting is much higher than normal planting. Combined application of organic manures and chemical fertilizers will enhance nutrient use efficiency. The field experiment was carried out at Raichur, Karnataka, India during 2017 to standardize rate of fertilizers and organic manures for Guava (Psidium guajava L.) Cv. Allahabad safeda under high density planting. Treatments consists of application of fertilizers for normal planting compared with 100:40:75 g NPK/plant as recommended dose of fertilizers (RDF), $75 \%$ and $50 \%$ of high density planting (HDP) along with $25 \mathrm{~kg}$ farmyard manure, organic manure alone and foliar application of urea @ $1 \%$ at 2,3 and 4 months after pruning. Results indicated that application of NPK@ 235: 118: $120 \mathrm{~g}$ per plant as per the RDF for HDP along with $25 \mathrm{~kg}$ FYM has resulted in taller plants, plant spread E-W as well as N-S directions, canopy volume and leaf area index. Higher fruits/plant, average fruit weight, fruit diameter, fruit length, fruit yield per plant and fruit yield (48.58 $\mathrm{t} \mathrm{ha}^{-1}$ ) was recorded by application of NPK@ 235: 118: $120 \mathrm{~g}$ per plant same as that of HDP along with $25 \mathrm{~kg} \mathrm{FYM.} \mathrm{Application} \mathrm{of} 50 \%$ of HDP recommendation along with foliar application of urea @ 1\% at 2, 3 and 4 months after pruning and $25 \mathrm{~kg}$ FYM was also found effective in achieving higher fruit yield of guava.
\end{abstract}

Keywords: Canopy volume, Fruit yield, Leaf area index, Guava, HDP

\section{Article Info}

DOI:10.31018/jans.v11i2.1668 Received: March 8, 2019

Revised: May 17, 2019

Accepted: June 1, 2019

\section{How to Cite}

Mushtaq et al. (2019). Nutrient requirement, canopy development and fruit yield of high density guava (Psidium guajava L.) production in subtropics of Northern Karnataka. Journal of Applied and Natural Science, 11(2): 440 - 444 https://doi.org/10.31018/ jans.v11i2.1668

\section{INTRODUCTION}

Guava (Psidium guajava L.) is one of the most important subtropical fruit crop widely distributed all over the equatorial regions of the tropical and sub tropical climate (Menzel and Poxtoni, 1985). The fruit is used for table and making juice, jellies, jam, paste, baby foods, syrup, wine and other processed products. In India, guava occupies an area of 268.22 thousand hectares with a productivity of 13.7 metric tonnes ha $^{-1}$ (Anon., 2014). Among the various factors nutrient management has significant influence on productivity of guava. Insufficient application of nutrients at flowering and fruit development adversely affect the produc- tivity and quality of produce. Under traditional planting system of guava, nutrient management practices have been well standardized. A sizeable quantity of nutrients is removed by fruits. Required quantity of nutrients must be replenished in the form of manures and fertilizers. Need to standardize rate, method, source and time of fertilizer application under high density planting system to attain long term sustainable fruit yield as well as soil productivity. Information on optimum quantity of nutrient requirement for high density planting guava is very meagre especially in subtropical peninsular India. Keeping these facts, field investigation was conducted with an objective to find out quantity of fertilizers along with organic manure 
required for high density guava and its influence on growth and yield.

\section{MATERIALS AND METHODS}

Experimental site: Field experiment was conducted at the Main Agricultural Research Station $\left(16^{\circ} 15 \mathrm{~N}, 77^{\circ} 21^{\prime} \mathrm{E}\right.$ and $389 \mathrm{~m}$ above mean sea level), College of Agriculture, University of Agricultural Sciences, Raichur, Karnataka, India during 2016-17. Treatments were imposed on four years old Guava plants cv. Allahabad Safeda.

Treatment details: Treatments consists of RDF for normal planting @ 100:40:75 g NPK/plant +25 kg FYM $\left(T_{1}\right)$, RDF for high density planting @ 235:118:120 g NPK/plant + 25kg FYM $\left(\mathrm{T}_{2}\right), 75 \%$ of $\mathrm{T}_{2}+25 \mathrm{~kg} \mathrm{FYM}\left(\mathrm{T}_{3}\right), \quad 50 \%$ of $\mathrm{T}_{2}+25 \mathrm{~kg} \mathrm{FYM}$ $\left(\mathrm{T}_{4}\right), 75 \%$ of $\mathrm{T}_{2}+\mathrm{FYM}$ equivalent to $58.75 \mathrm{~g} \mathrm{~N}$ $\left(\mathrm{T}_{5}\right), 50 \%$ of $\mathrm{T}_{2}+\mathrm{FYM}$ equivalent to $117.5 \mathrm{~g} \mathrm{~N}\left(\mathrm{~T}_{6}\right)$, $100 \% \mathrm{~N}$ through FYM $\left(\mathrm{T}_{7}\right), 50 \% \mathrm{~T}_{2}+25 \mathrm{~kg}$ FYM+ foliar application of $1 \%$ urea at 2, 3 and 4 month after pruning $\left(T_{8}\right)$ tested in randomized block design with three replications. The $\mathrm{N}, \mathrm{P}$ and $\mathrm{K}$ content of FYM used in the experiment was $0.5,0.2$ and 0.5 respectively. Quantity of fertilizers used in each treatment is provided in table 1. Under high density planting plants are planted at a spacing of $3.0 \mathrm{~m} \times 3.0 \mathrm{~m}$ (1,111 plants/ha).

Growth and yield attributes: The growth parameters such as plant height, plant spread, length and girth of new tertiary shoot, productive and unproductive shoots per plant, canopy volume, and physiological parameter such as leaf area, leaf area index were recorded at 60, 120 and 180 days after pruning. Leaf area index was measured by using SunScan Canopy analyzer (Delta-T, UK). The observations on fruits per plant, average fruit weight, fruit length and diameter, yield per plant and hectare were recorded at harvest stage.

Statistical analysis: The data collected on different parameters during the course of investigation were subjected to statistical analysis using randomized complete block design of Fischer method of analysis of variance and interpretation of data was done as per the procedure described by Panse and Sukhatme (2000).

\section{RESULTS AND DISCUSSION}

Application of graded levels of NPK fertilizers along with organic manure showed beneficial effect on plant growth as well as fruit yield of guava (Table 2). Significant variation in fruit yield in guava was recorded by varied application of fertilizers, organic manure and foliar spray. Fruit yield was greater by application of fertilizer @ 235:118:120 g/plant and $25 \mathrm{~kg}$ FYM (44.61 kg/ plant) and $50 \%$ of $\mathrm{T}_{2}$ in addition to $25 \mathrm{~kg} \mathrm{FYM}$ and foliar application of $1 \%$ urea at 2, 3 and 4 month after pruning (42.85 kg/plant). It was 25 and 20 higher than current recommendation of normal planting. It was related to variation in vegetative growth throughout the crop growth period after pruning, the major growth attributes of guava viz, plant height, canopy spread, canopy volume, leaf area index, and leaf chlorophyll content (Fig. 1). Significant differences in growth parameters was observed by application of @ 235: 118: $120 \mathrm{~g}$ NPK per plant along with $25 \mathrm{~kg}$ FYM as per the RDF for high density planting guava, it was followed by $50 \%$ of the recommended dose fertilizers for high density planting along with foliar application of urea @ 1\% at 2, 3 and 4 months after pruning and $25 \mathrm{~kg}$ FYM. Significant reduction in all the growth parameters was observed in application of organic manure on nitrogen equivalent bases. It might be due to insufficient quantity of nutrients required for plant growth.

Similarly reducing the level of fertilizers of high density planting recommendation either $50 \%$ or $75 \%$ didn't significantly influence on all the growth attributes. Vandana Dwivedi (2013) and Maity et al. (2016) also reported that significant improvement in fruit yield of guava was observed by application of graded levels of fertilizers along with organic manures. It was attributed to association of nitrogen in synthesis of protoplasm, primary manufacturing of amino acid and enhanced auxin activity brought about by sufficient nitrogen fertilizers (Atom, 2013 and Reddy et al., 2000). It has resulted in enhanced meristamatic activities in terms of vegetative growth. The phosphorus also involved in photosynthesis and constituent of nucleo- proteins, synthesis of starch, sucrose and protein. Application of sufficient quantity of phosphorus might have helped in synthesis of above growth compounds required for better growth of guava. Similarly potassium also involved in development of canopy

Table 1. Details of $\mathrm{N}, \mathrm{P}_{2} \mathrm{O}_{5}$ and $\mathrm{K}_{2} \mathrm{O}$ nutrient applied (g/plant) through chemical fertilizers and farmyard manure per tree of Guava.

\begin{tabular}{llllllllll}
\hline Treatment & \multicolumn{3}{c}{ From Chemical Fertilizers } & \multicolumn{3}{c}{ From FYM } & \multicolumn{3}{c}{ Total } \\
\cline { 2 - 10 } & $\mathbf{N}$ & $\mathbf{P}_{\mathbf{2}} \mathbf{O}_{\mathbf{5}}$ & $\mathbf{K}_{\mathbf{2}} \mathbf{O}$ & $\mathbf{N}$ & $\mathbf{P}_{\mathbf{2}} \mathbf{O}_{5}$ & $\mathbf{K}_{\mathbf{2}} \mathbf{O}$ & $\mathbf{N}$ & $\mathbf{P}_{\mathbf{2}} \mathbf{O}_{5}$ & $\mathbf{K}_{\mathbf{2}} \mathbf{O}$ \\
\hline $\mathrm{T}_{1}$ & 100 & 40 & 75 & 130 & 57.5 & 145 & 230.0 & 97.5 & 220.0 \\
$\mathrm{~T}_{2}$ & 235 & 118 & 120 & 130 & 57.5 & 145 & 365.0 & 175.5 & 265.0 \\
$\mathrm{~T}_{3}$ & 176.25 & 88.5 & 90 & 130 & 57.5 & 145 & 306.3 & 146.0 & 235.0 \\
$\mathrm{~T}_{4}$ & 117.5 & 59 & 60 & 130 & 57.5 & 145 & 247.5 & 116.5 & 205.0 \\
$\mathrm{~T}_{5}$ & 176.25 & 88.5 & 90 & 61.1 & 27.025 & 68.15 & 237.4 & 115.5 & 158.2 \\
$\mathrm{~T}_{6}$ & 117.5 & 59 & 60 & 122.2 & 54.05 & 136.3 & 239.7 & 113.1 & 196.3 \\
$\mathrm{~T}_{7}$ & 0 & 40 & 75 & 100 & 108.1 & 272.6 & 100.0 & 148.1 & 347.6 \\
$\mathrm{~T}_{8}$ & 186.5 & 59 & 60 & - & - & - & 186.5 & 59.0 & 60.0 \\
\hline
\end{tabular}


Mushtaq et al. / J. Appl. \& Nat. Sci. 11(2): 440 - 444 (2019)

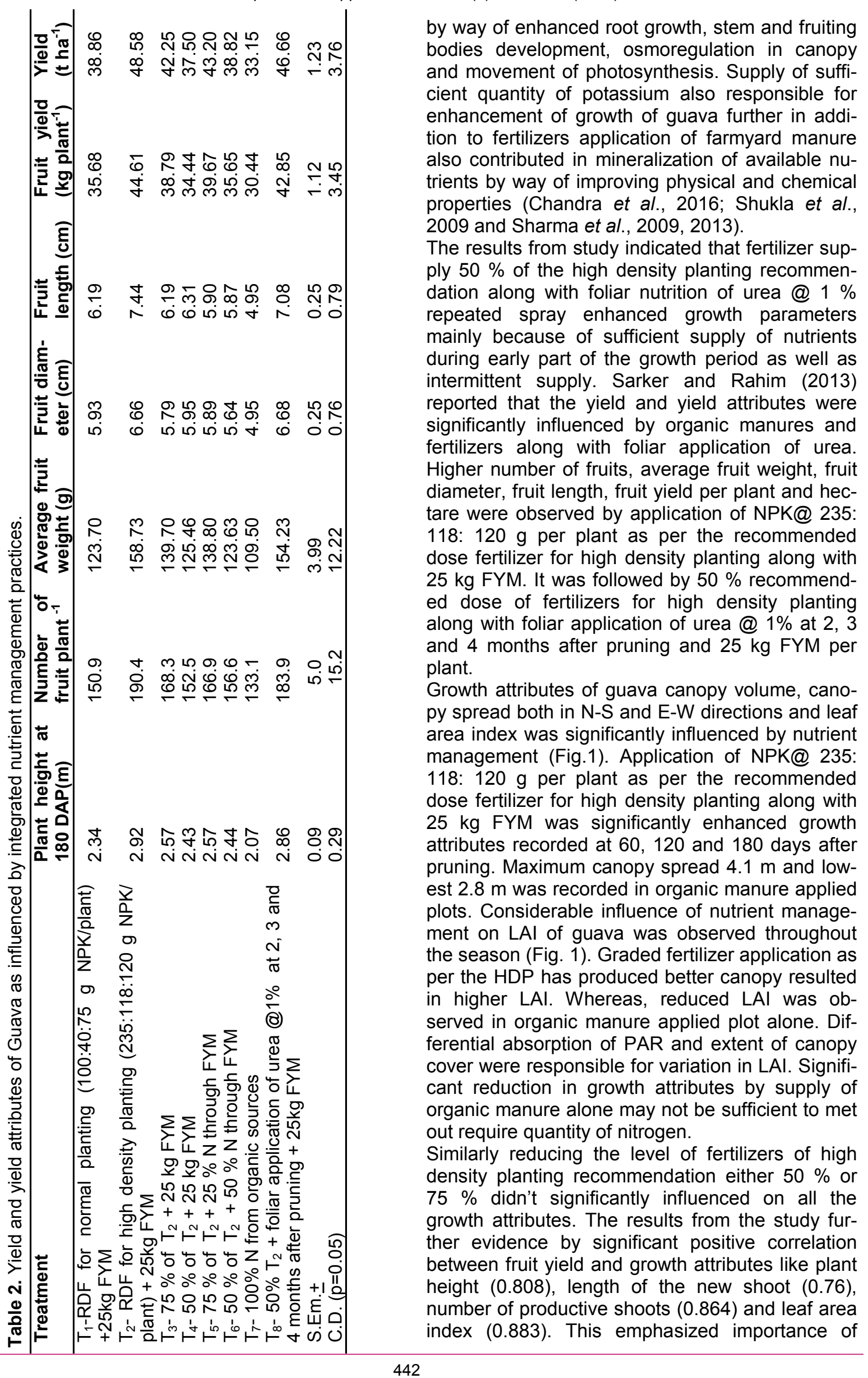


Mushtaq et al. / J. Appl. \& Nat. Sci. 11(2): 440 - 444 (2019)

Table 3. Relationship between growth, yield and quality parameters of guava as influenced by integrated nutrient management practices.

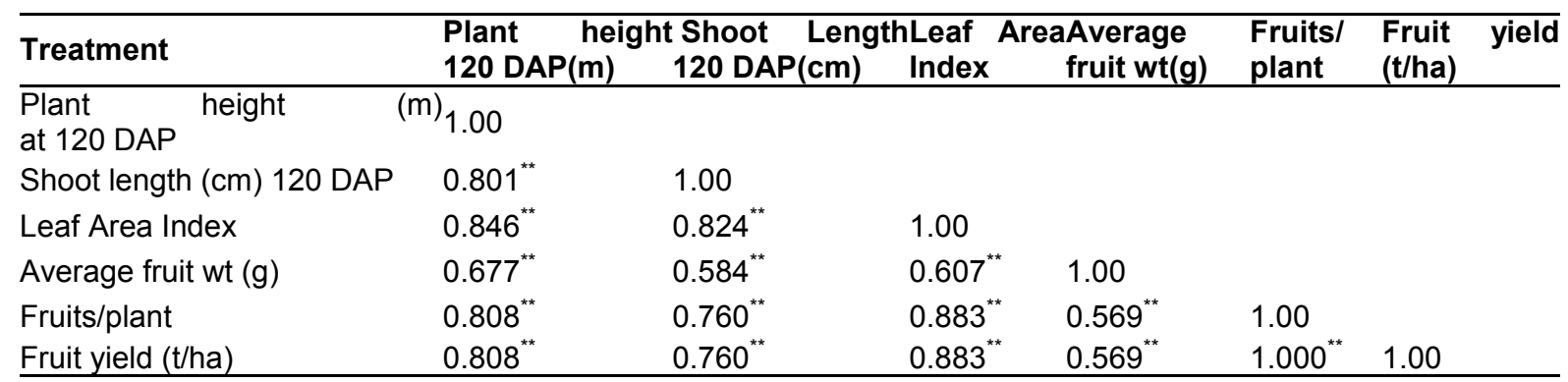

${ }^{* *}$ - significant at $p=0.05$
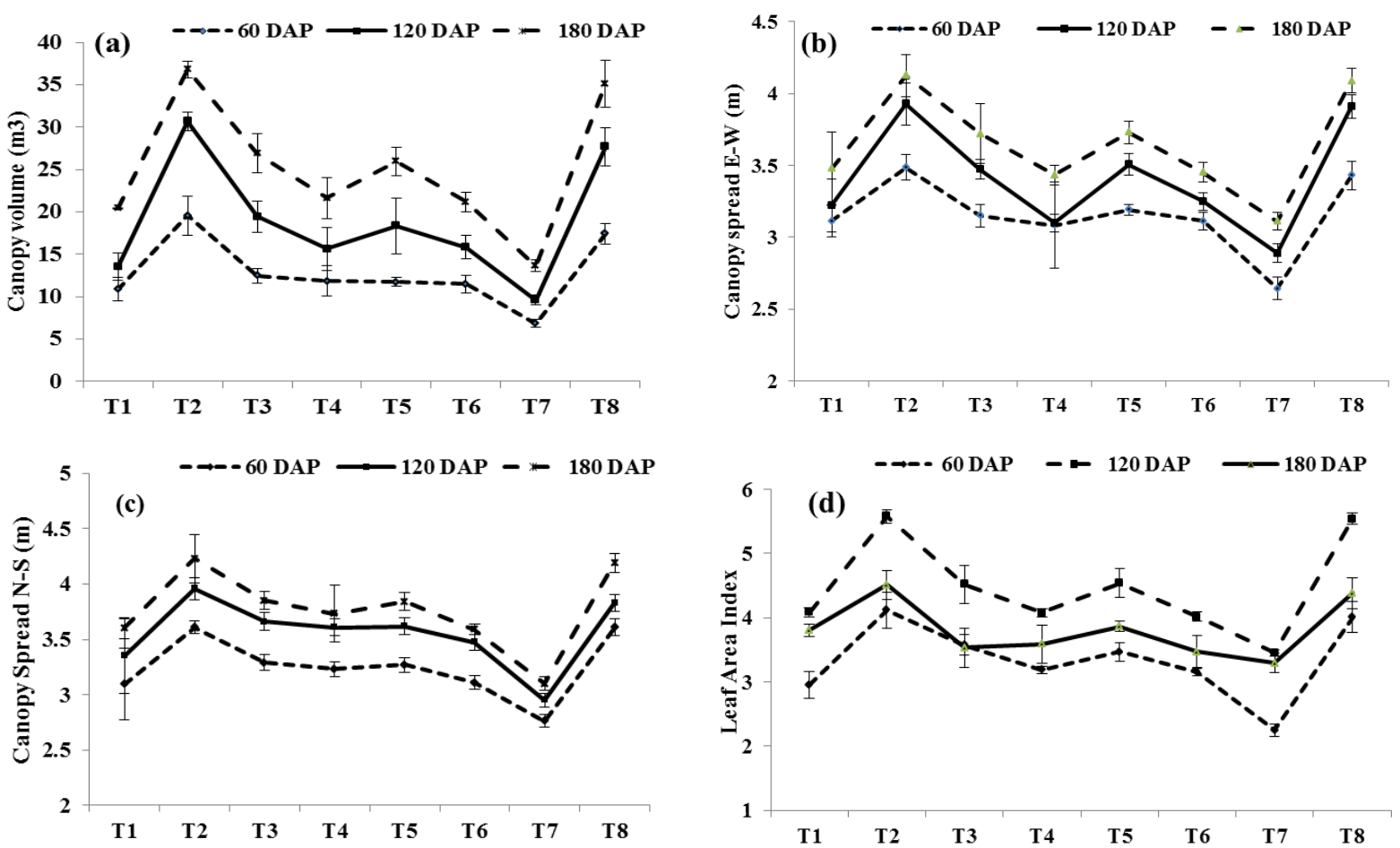

Fig. 1. Canopy volume (a), Canopy spread E-W direction (b), Leaf area index (c) and canopy spread N-S direction (d) as influenced by nutrient management practices in guava (Details of $T_{1}$ to $T_{8}$ in Table 1).

these parameters in achieving higher fruit yield (Table 3).

For high density planting nutrient requirement was obviously much higher than normal planting. Application of fertilizers as well as foliar nutrition through urea was found sufficient to meet nutrient requirement of high density guava. Further improvement in yield is governed by several attributes throughout growth period, the factors which have directly influenced on yield and yield components viz., number of fruits per plant, average fruit weight, fruit diameter, fruit length, fruit yield per plant and number of productive shoots. Garhwal et al. (2014) and Imran Arshad (2015) also reported fruit yield per plant, fruit diameter, and individual fruit weight and fruit yield of guava were significantly influenced by integrated nutrient management. Further, recent evidences also indicated that application of fertilizers along with organic manure and bio-fertilizers have significant influence on guava fruit yield reported by Shukla et al. (2009). Application of nutrients through foliar spray at different intervals after pruning enhance fruit yield, was mainly due to intermittent supply of nutrient that may enhance fruiting bodies as indicated by more number of reproductive shoots. The result of present study also confirm of with the finding of Jat and Kacha (2014).

\section{Conclusion}

Results of the study indicated that application of graded @ 235:118:120 g NPK/plant + 25 kg FYM per plant enhanced $25 \%$ higher fruit yield in high density planting as compared to present recommendation. Further, quantity of chemical fertilizers 
can be reduced by substitution of $50 \%$ of recommended $\mathrm{N}$ along with foliar application of urea $@ 1 \%$ at 2, 3 and 4 months after pruning $+25 \mathrm{~kg}$ FYM. It also enhanced growth of individual plants measured by canopy spread, volume and leaf area index.

\section{REFERENCES}

1. Anonymous (2014). Indian Horticulture Database, National Horticulture Board, Ministry of Agriculture, Government of India, Gurgaon, India. Website: www.nhb.gov.in.

2. Atom A. (2013). Effect of inorganic and biofertilizers on growth, yield and quality of Sardar guava (Psidium guajava L.). M.Sc., Thesis, College of Agriculture, Latur.

3. Chandra, Vikas, Sharma HG and Dikshit SN (2016). Effect of chemical fertilizers, organics manure and biofertilizers on growth, yield and quality of mrigbahar guava (Psidium guajava).Curr. Adv. Agril. Sci., 8(1): 114-116.

4. Garhwal PC, Yadav PK, Sharma BD, Singh RS and Ramniw AS (2014). Effect of organic manure and nitrogen on growth, yield and quality of kinnow mandarin in sandy soils of hot arid region. African $\mathrm{J}$. Agric.Res., 9(34): 2638-2647.

5. Imran Arshad (2015). Integrated application of NPK fertilizers on the growth and yield of guava (Psidium guajava L.) in arid region of lower Sindh, Pakistan. Int. Res. J. PI. Crop Sci., 2(1): 019-023.

6. Jat, Giriraj and Kacha, HL (2014). Response of guava to foliar application of urea and zinc on fruit set, yield and quality. J. Agri.Search.,1(2): 86-91.

7. Maity PK, Das BC and Kundu S (2006). Effect of different sources of nutrients on yield and quality of guava cv.L-49.J. Crop Weed, 2(2):17-19.

8. Menzel CM and Paxtoni BF (1985).The pattern of growth flowering and fruiting of guava varieties in subtropical owns land. Australian J. Expt. Agric., 26: 123-127.

9. Panse VG and Sukhatme PV (1985). Statistical method of agricultural workers, I. C.A.R., New Delhi.

10.Reddy YTN, Kurian RM, Kohli RR and Gorakh Singh (2000). Effect of nitrogen, phosphorous and potassium on growth, yield and quality of Totapuri mango (Mangifera indica). Indian J. Agril. Sci., 70(7): 475478.

11.Sarker BC and Rahim MA, (2013). Yield and quality of mango (Mangifera indica L.) as influenced by foliar application of potassium nitrate and urea. Bangladesh J. Agril., Res., 38(1): 145-154.

12.Sharma A, Wali VK, Bakshi $P$ and $J$ Asrotia A, (2013). Effect of organic and inorganic fertilizers on quality and shelf life of guava (Psidium guajava L.) cv. sardar. The Bio-Scan J. Life Sci., 8(4): 12471250.

13.Sharma, Akash, Kher R, Wall VX and Baksm Parshant, (2009). Effect of biofertilizers and organic manures on physico-chemical characteristics and soil nutrient composition of guava (Psidium guajava L.) cv. Sardar. J. Res., 8(2):150- 156.

14.Shukla AK, Sarolia DK, Kumari B, Kaushik RA, Mahawer LN and Bairwa HL (2009). Evaluation of substrate dynamics for integrated nutrient management under high density planting of guava cv. Sardar. Indian J. Hort.,66(4): 461-464.

15.Vandana Dwivedi (2013). Effect of integrated nutrient management on yield, quality and economics of guava. Annals Soil Res., 15(2): 149-151. 